\title{
Prevalence of ESBL and MBL Producing Gram Negative Isolates from Various Clinical Samples in a Tertiary Care Hospital
}

\author{
Narinder Kaur ${ }^{*}$, Amandeep Kaur ${ }^{2}$ and Satnam Singh ${ }^{3}$ \\ ${ }^{1}$ Department of Microbiology, Adesh Medical College and Hospital, Ambala, India \\ ${ }^{2}$ Department of Microbiology, ${ }^{3}$ Department of Pharmacology, \\ Adesh institute of Medical Sciences and Research, Bathinda, India \\ *Corresponding author
}

\section{A B S T R A C T}

\begin{tabular}{|l|}
\hline Ke y w o r d s \\
Gram Negative, \\
ESBL, MBL, \\
Antibiotic \\
resistance, \\
Beta lactamases, \\
Infection Control, \\
Antibiotic Policy. \\
\hline Article Info \\
\hline Accepted: \\
12March 2017 \\
Available Online: \\
10 April 2017 \\
\hline
\end{tabular}

\begin{abstract}
Antimicrobial resistance is a growing threat worldwide. Increasing resistance to third generation cephalosporins has become a cause for concern. The prevalence of extended spectrum-lactamases (ESBLs) and metallobetalactamases (MBL) among members of Enterobacteriaceae constitutes a serious threat to current -lactam therapy leading to treatment failure. A total of 276 Gram negative isolates were processed. ESBL was detected by phenotypic confirmatory disc diffusion test (PCDDT) using ceftazidime alone and in combination with clavulanic acid. MBL detection was done by Imipenem EDTA combined disc diffusion test and Modified Hodge test. Out of 276 isolates $69(25 \%)$ were ESBL producers, $70(25.3 \%)$ were MBL producers and $26(9.42 \%)$ were both ESBL and MBL producers. Highest ESBL production was seen in Escherichia coli (46\%) and maximum MBL production was seen in Klebsiella pneumoniae (34.8\%). The study underlines problem of ESBL and MBL mediated resistance, which has created a therapeutic challenge for the clinicians and microbiologists. Simple disk method can be routinely employed to detect these common resistance mechanisms which will reduce the mortality and also spread of such resistant strains.
\end{abstract}

\section{Introduction}

Antibiotic resistance among Gram-negative bacilli (GNB) is a rapidly expanding problem due to the organisms' ability to mutate, and to acquire and transmit plasmids and other mobile genetic elements encoding resistance gene. Beta-lactamase antibiotics are among the most widely prescribed antibiotics worldwide and the emergence of resistance to these agents has resulted in a major clinical crisis (Siddiqui et al., 2014). The $\beta$ - lactam group of antibiotics is widely used to treat the infections caused by the pathogenic bacteria. Due to the extensive use of these antibiotics, $\beta$ - lactamase mediated resistance has raised as major clinical crisis. The newer $\beta$-lactamases, including extended-spectrum $\beta$ lactamases (ESBLs), ampC $\beta$-lactamases $(\mathrm{AmpC})$, and metallo- $\beta$-lactamases (MBLs) have emerged worldwide as a cause of antimicrobial $\beta$ - lactamase mediated resistance in gram negative bacteria (Kumar et al., 2013). ESBLs are still considered as a threat since they are coded by plasmid and can be easily transmitted between species. ESBL producing oraganisms are highly effective in inactivating penicillins, most cephalosporins and aztreonam and are inhibited by $\beta$ - lactamase inhibitors such as clavulanic acid (Fam et al., 2006). ESBL producing isolates, in addition to being 
resistant to $\beta$-lactam antibiotics, often exhibit resistance to other classes of drugs such as aminoglycosides, cotrimoxazole, tetracycline and fluoroquinolones. ESBLs are often located on plasmids that are transferable from strain to strain (Kamble, 2015). Carbapenems are used as drug of choice to treat infections caused by beta-lactam resistant bacteria. But extensive and sometimes unnecessary use of the carbapenems, poor sanitation and large population has facilitated the emergence of carbapenem resistant bacteria (Wadekar et al., 2013).

Resistance to these antibiotics is due to decreased outer membrane permeability, increased efflux systems, alteration of penicillin binding proteins and carbapenem hydrolyzing enzymes carbapenemases (Kamalraj et al., 2015). Resistance to carbapenem is predominantly mediated by metallo betalactamases, a class B type of betalactamases that recognize bivalent metal ions (Anil Rajput et al., 2012). MBL can hydrolyze all metallo beta lactams except monobactams and are not inactivated by beta lactamase inhibitors like clavulanic acid, sulbactam and tazobactam (Chakraborty et al., 2010). They may be chromosomally or plasmid mediated and therefore poses a threat of spread of resistance by gene transfer among gram negative bacteria (Kamalraj et al., 2015).

The aim of the current study is to determine the percentage of ESBL and MBL producers among gram negative clinical isolates. Early detection of ESBL and MBL producing organisms is crucial to establish appropriate antimicrobial therapy and to prevent their inter hospital dissemination.

\section{Materials and Methods}

A total of 276 Gram negative organisms were isolated from various clinical samples (urine, pus, blood, ET secretions, tracheal aspirates. They were identified by standard microbiological procedures (Collee et al., 2007). The susceptibility of isolates to antibiotics was determined by Kirby- Bauer disc diffusion method using Clinical and Laboratory Standard Institute guidelines (CLSI, 2016). Antibiotics included were cetazidime $(30 \mu \mathrm{g})$, aztreonam $(30 \mu \mathrm{g})$, cefipime $(30 \mu \mathrm{g})$, cefotaxime $(30 \mu \mathrm{g})$, cefoxitin $(30 \mu \mathrm{g})$, imipenem $(10 \mu \mathrm{g})$, meropenem $(10 \mu \mathrm{g})$, cefoperazone/ sulbactam $(75 / 30 \mu \mathrm{g})$, piperacillin/ tazobactam (100/10 $\mu \mathrm{g})$, gentamicin $(10 \mu \mathrm{g})$, amikacin $(30 \mu \mathrm{g})$, ciprofloxacin $(5 \quad \mu \mathrm{g}), \quad$ cotrimoxazole $(1.25 / 23.75 \mu \mathrm{g})$, polymxin $\mathrm{B}(300 \mathrm{U})$ and colistin $(10 \mu \mathrm{g})$.

Isolates resistant to third generation cephalosporins were tested for ESBL production and isolates showing resistance to imipenem were tested for MBL production. Phenotypic detection of ESBL: The double disk diffusion method was used for detection of this enzyme as recommended by CLSI (CLSI, 2016). The suspension was streaked onto Mueller-Hinton agar plates (Hi Media, Mumbai, India). A disc of either ceftazidime $(30 \mu \mathrm{g})$ or cefotaxime alone $(30 \mu \mathrm{g})$ in combination with clavulanic acid $(30 \mu \mathrm{g} / 10$ $\mu \mathrm{g})$ was placed at the distance of $20 \mathrm{~mm}$ (centre to centre). After incubation overnight at $35^{\circ} \mathrm{C}$, a positive test result was considered as a $5 \mathrm{~mm}$ increase in inhibition zone compared with a disk without clavulanic acid. Phenotypic detection of MBL: Imipenem resistant isolates were screened for production of MBL by double disc diffusion test and modified Hodge test and strains showing positive results by both the methods are considered MBL producers.

\section{Double disc diffusion test}

Commercially available imipenem $(10 \mu \mathrm{g})$ and imipenem/EDTA $(10+750 \mu \mathrm{g}) \quad$ (Hi-media, 
Mumbai) discs were placed on the Mueller Hinton agar at a distance of $20 \mathrm{~mm}$ each other. After the incubation period of 16-18 hours at $37^{\circ} \mathrm{C}$, the increase in inhibition zone size $\geq$ $7 \mathrm{~mm}$ around the IMP/EDTA disc than the IMP alone was considered as MBL positive (Yong et al., 2002).

\section{Modified Hodge test}

An overnight culture of E. coli ATCC 25922 was adjusted to $0.5 \mathrm{McF}$ arland standard and lawn culture was made on Muller Hinton agar (Hi-media, Mumbai). The $10 \mu \mathrm{g}$ of imipenem was placed on the centre of the plate and test culture was streaked from the edge of the disc to the periphery of the plate. After the incubation period of 16-18 hours at $370 \mathrm{C}$, the presence of a cloverleaf zone or distortion of inhibition around the imipenem disc was interpreted as positive for MBL production (CLSI, 2016).

\section{Results and Discussion}

The emergence of antibiotic resistance is a matter of great concern, particularly in hospitals. Antibiotic resistant bacteria appear to be biologically fit and capable of causing serious life threatening infections. The increase in antibiotic resistance among gramnegative bacilli, such as Enterobacteriaceae group, Pseudomonas aeruginosa and others, is a notable example and how bacteria can procure, maintain and express new genetic information that can confer resistance to one or several antibiotics. Resistance in gramnegative bacteria is a serious problem and calls for an effective infection control measures to curb their dissemination (Walsh et al., 2005; Bradford, 2001). A total of 276 Gram negative organisms were isolated and further processed as study group. Out of 276 Gram negative isolates, Escherichia coli (41.6\%) was the most common organism isolated followed by Klebsiella pneumoniae(24\%) and Pseudomonas spp (17.7\%) (Table 1). Antibiotic resistance profile of various gram negative isolates is shown in table 2 . Isolates resistant to third generation cephalosporins were tested for ESBL production and isolates showing resistance to imipenem were tested for MBL production.

Among 276 gram negative isolates 69(25\%) were ESBL producers, 70(25.3\%) were MBL producers and 26(9.42\%) were both ESBL and MBL producers (Table 3).

In the present study 34(49.2\%) ESBL producers were from IPD patients and $18(26 \%)$ were from OPD patients. Amongst the MBL producers $28(40 \%)$ were from IPD patients and 14(20\%) were from OPD patients (Table 4). Our results showing high percentage of ESBL and MBL production in IPD patients were similar to findings of Oberoi et al., (2013), Deshmukh et al., (2011) and Prajapati et al., (2013). These results corroborates the fact that a lot of risk factors associated with infections exist in indoor and ICU patients like environmental reservoir for multidrug resistant organisms, opportunities of cross transmission, sick and immunocompromised patients who are colonized, patients having multiple wounds and indwelling devices, heavy use of broad spectrum antibiotics and frequent contamination of the hands of health care workers while patient care. Highest ESBL production was seen in Escherichia coli (46\%) followed by Klebsiella pneumonia $(21.2 \%)$ (Table 5), which is comparable with studies by Kamble (2015), Agarwal et al., (2008), Tsering et al., (2008) and Shiju et al., (2010). In our study highest MBL production was seen in Klebsiella pneumoniae (34.8\%) and Pseudomonas spp (34.6\%) (Table 5), which is comparable to studies conducted by Oberoi et al., (2013), Kumar et al., (2012) and Rao et al., (2013). 
Table.1 Distribution of various Gram negative isolates ( $N=276)$

\begin{tabular}{|l|c|}
\hline Escherichia coli & $115(41.6 \%)$ \\
\hline Klebsiella pneumoniae & $\mathbf{6 6}(24.0 \%)$ \\
\hline Pseudomonas spp & $49(17.7 \%)$ \\
\hline Acinetobacter spp & $25(9.1 \%)$ \\
\hline Citrobacter spp & $9(3.3 \%)$ \\
\hline Proteus spp & $7(2.5 \%)$ \\
\hline Enterobacter spp & $5(1.8 \%)$ \\
\hline
\end{tabular}

Table.2 Resistance pattern (\% resistance) of various gram negative isolates ( $\mathrm{N}=276)$

\begin{tabular}{|c|c|c|c|c|c|c|c|}
\hline $\begin{array}{c}\text { Antibiotic } \\
\text { Tested }\end{array}$ & 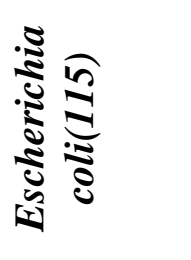 & 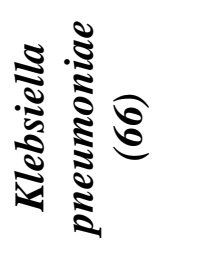 & 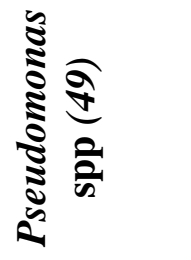 & 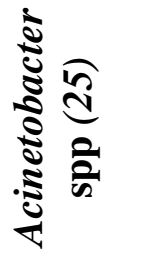 & 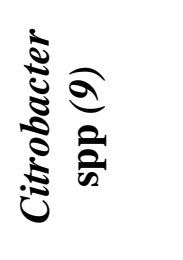 & 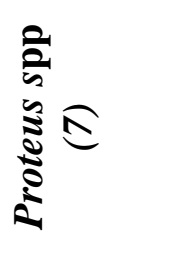 & 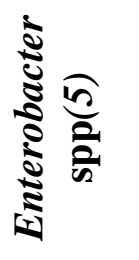 \\
\hline Ceftazidime & $77(66.9 \%)$ & $39(59 \%)$ & $28(57.1 \%)$ & $22(88 \%)$ & $7(77.7 \%)$ & $6(85.7 \%)$ & $4(80 \%)$ \\
\hline Ceftriaxone & $75(65.2 \%)$ & $38(57.5 \%)$ & NT & $23(92 \%)$ & $7(77.7 \%)$ & $6(85.7 \%)$ & $4(80 \%)$ \\
\hline Cefefime & $69(60 \%)$ & $25(53.0 \%)$ & $20(40.8 \%)$ & $20(80 \%)$ & $7(77.7 \%)$ & $4(57.1 \%)$ & $3(60 \%)$ \\
\hline $\begin{array}{l}\text { Cefoperazone- } \\
\text { Sulbactam }\end{array}$ & $69(60 \%)$ & $36(54.5 \%)$ & $13(26.5 \%)$ & $18(72 \%)$ & $5(55.5 \%)$ & $4(57.1 \%)$ & $3(60 \%)$ \\
\hline $\begin{array}{l}\text { Piperacillin- } \\
\text { Tazobactam }\end{array}$ & $69(60 \%)$ & $32(48.4 \%)$ & $19(38.7 \%)$ & $19(76 \%)$ & $6(66.6 \%)$ & $3(42.8 \%)$ & $2(40 \%)$ \\
\hline Gentamicin & $72(62.6 \%)$ & $38(57.5 \%)$ & $16(32.6 \%)$ & $14(56 \%)$ & $5(55.5 \%)$ & $3(42.8 \%)$ & $3(60 \%)$ \\
\hline Amikacin & $64(55.6 \%)$ & $44(66.6 \%)$ & $11(22.4 \%)$ & $13(52 \%)$ & $6(66.6 \%)$ & $4(57.1 \%)$ & $1(20 \%)$ \\
\hline Ciprofloxacin & $51(44.3 \%)$ & $27(41 \% 0$ & $22(44.8 \%)$ & $17(68 \%)$ & $4(44.4 \%)$ & $5(71.4 \%)$ & $3(60 \%)$ \\
\hline Imipenem & $19(16.5 \%)$ & $33(50 \%)$ & $14(28.5 \%)$ & $16(66 \%)$ & $7(77.7 \%)$ & $6(85.7 \%)$ & $3(60 \%)$ \\
\hline Meropenem & $20(17.3 \%)$ & $33(50 \%)$ & $15(30.6 \%)$ & $18(72 \%)$ & $6(66.6 \%)$ & $6(85.7 \%)$ & $3(60 \%)$ \\
\hline Cotrimoxazole & $37(32.1 \%)$ & $36(54.5 \%)$ & NT & $20(80 \%)$ & $8(88.8 \%)$ & $7(100 \%)$ & $4(80 \%)$ \\
\hline Polymixin B & $0(0 \%)$ & $0(0 \%)$ & $0(0 \%)$ & $0(0 \%)$ & $0(0 \%)$ & NT & $0(0 \%)$ \\
\hline Colistin & $0(0 \%)$ & $0(0 \%)$ & $0(0 \%)$ & $0(0 \%)$ & $0(0 \%)$ & NT & $0(0 \%)$ \\
\hline
\end{tabular}

Table.3 Percentage of ESBL and MBL producers among total Gram negative isolates

\begin{tabular}{|c|c|}
\hline Total GNB isolates & $\mathbf{2 7 6}$ \\
\hline ESBL producers & $\mathbf{6 9}(25 \%)$ \\
\hline MBL producers & $\mathbf{7 0}(25.3 \%)$ \\
\hline Both ESBL and MBL producer & $\mathbf{2 6}(\mathbf{9 . 4 2 \%})$ \\
\hline
\end{tabular}


Table.4 Area wise distribution of ESBL and MBL producers

\begin{tabular}{|l|l|l|l|}
\hline & OPD & IPD & ICU \\
\hline ESBL producers (N=69) & $\mathbf{1 8}(\mathbf{2 6 \%})$ & $\mathbf{3 4}(49.2 \%)$ & $\mathbf{1 7}(\mathbf{2 4 . 7 \%})$ \\
\hline MBL producers (N=70) & $\mathbf{1 4}(20 \%)$ & $\mathbf{2 8}(40 \%)$ & $\mathbf{2 8}(40 \%)$ \\
\hline $\begin{array}{l}\text { Both ESBL and MBL } \\
\text { producers }(\mathbf{N}=26)\end{array}$ & $\mathbf{4}(15.4 \%)$ & $12(46.2 \%)$ & $10(38.4 \%)$ \\
\hline Total $(\mathbf{N}=165)$ & 36 & 74 & 55 \\
\hline
\end{tabular}

Table.5 ESBL and MBL producers among various isolates

\begin{tabular}{|c|c|c|c|c|}
\hline Organism & $\begin{array}{l}\text { No. of } \\
\text { isolates }\end{array}$ & $\begin{array}{c}\text { ESBL producers } \\
\text { No. }(\%)\end{array}$ & $\begin{array}{l}\text { MBL producers } \\
\text { No. }(\%)\end{array}$ & $\begin{array}{c}\text { Both ESBL and } \\
\text { MBL producers } \\
\text { No. }(\%)\end{array}$ \\
\hline Escherichia coli & 115 & $53(46.08 \%)$ & $17(14.7 \%)$ & $7(6.08 \%)$ \\
\hline $\begin{array}{l}\text { Klebsiella } \\
\text { pneumoniae }\end{array}$ & 66 & $14(21.2 \%)$ & $23(34.8 \%)$ & $5(7.57 \%)$ \\
\hline Pseudomonas spp & 49 & $1(2.04 \%)$ & $17(34.6 \%)$ & $6(12.2 \%)$ \\
\hline Acinetobacter spp & 25 & $1(4 \%)$ & $7(28 \%)$ & $5(20 \%)$ \\
\hline Citrobacter spp & 9 & $\mathbf{0}(\mathbf{0 \%})$ & $3(33.3 \%)$ & $2(22.2 \%)$ \\
\hline Proteus spp & 7 & $\mathbf{0}(\mathbf{0 \%})$ & $2(28.5 \%)$ & $1(25 \%)$ \\
\hline Enterobacter spp & 5 & $\mathbf{0}(\mathbf{0 \%})$ & $1(20 \%)$ & $\mathbf{0}(\mathbf{0 \%})$ \\
\hline Total & 276 & $69(25 \%)$ & $70(25.3 \%)$ & $26(9.42 \%)$ \\
\hline
\end{tabular}

Table.6 Sample wise distribution of various ESBL positive isolates

\begin{tabular}{|c|c|c|c|c|c|c|}
\hline ESBL producer & $\begin{array}{c}\text { No. of } \\
\text { isolates }\end{array}$ & Urine & Pus & $\begin{array}{c}\text { High } \\
\text { vaginal } \\
\text { swabs }\end{array}$ & $\begin{array}{c}\text { ET } \\
\text { Secretions }\end{array}$ & Sputum \\
\hline Escherichia coli & 53 & $34(64.1 \%)$ & $15(41.5 \%)$ & $3(5.6 \%)$ & $\mathbf{0}(\mathbf{0 \%})$ & $1(1.8 \%)$ \\
\hline Klebsiella pneumoniae & 14 & $6(42.8 \%)$ & $6(42.8 \%)$ & $\mathbf{0}(\mathbf{0 \%})$ & $1(7.14 \%)$ & $1(7.1 \%)$ \\
\hline Pseudomonas spp & 1 & $0(0 \%)$ & $\mathbf{0}(\mathbf{0 \%})$ & $0(0 \%)$ & $1(100 \%)$ & $0(0 \%)$ \\
\hline Acinetobacter spp & 1 & $0(0 \%)$ & $1(100 \%)$ & $\mathbf{0}(\mathbf{0 \%})$ & $0(0 \%)$ & $0(0 \%)$ \\
\hline Total & 69 & $40(58 \%)$ & $22(31.8 \%)$ & $3(4.3 \%)$ & $2(2.89 \%)$ & $2(2.89 \%)$ \\
\hline
\end{tabular}


Table.7 Sample wise distribution of various MBL positive isolates $(\mathrm{N}=70)$

\begin{tabular}{|c|c|c|c|c|c|c|c|c|}
\hline $\begin{array}{c}\text { MBL } \\
\text { producer }\end{array}$ & $\begin{array}{c}\text { No of } \\
\text { isolates }\end{array}$ & $\begin{array}{c}\text { Urine } \\
(\mathbf{1 7})\end{array}$ & $\begin{array}{c}\text { Pus } \\
(\mathbf{1 8})\end{array}$ & $\begin{array}{c}\text { Blood } \\
\mathbf{( 4 )}\end{array}$ & $\begin{array}{c}\text { ET } \\
\text { secretions } \\
(\mathbf{1 2})\end{array}$ & $\begin{array}{c}\text { Tracheal } \\
\text { aspirate } \\
(\mathbf{1 1})\end{array}$ & $\begin{array}{c}\text { Sputum } \\
\mathbf{( 4 )}\end{array}$ & $\begin{array}{c}\text { Central } \\
\text { Line tip } \\
\mathbf{( 4 )}\end{array}$ \\
\hline $\begin{array}{c}\text { Escherichia } \\
\text { coli }\end{array}$ & 17 & $8(47.05 \%)$ & $3(17.6 \%)$ & $1(5.8 \%)$ & $2(11.7 \%)$ & $2(11.7 \%)$ & $0(0 \%)$ & $1(5.8 \%)$ \\
\hline $\begin{array}{c}\text { Klebsiella } \\
\text { pneumoniae }\end{array}$ & 23 & $2(8.7 \%)$ & $7(30.4 \%)$ & $0(0 \%)$ & $3(13 \%)$ & $6(26 \%)$ & $2(8.7 \%)$ & $3(13 \%)$ \\
\hline $\begin{array}{c}\text { Pseudomonas } \\
\text { spp }\end{array}$ & 17 & $6(35.3 \%)$ & $4(23.5 \%)$ & $2(11.7 \%)$ & $3(17.6 \%)$ & $2(11.7 \%)$ & $0(0 \%)$ & $0(0 \%)$ \\
\hline $\begin{array}{c}\text { Acinetobacter } \\
\text { spp }\end{array}$ & 7 & $0(0 \%)$ & $1(14.2 \%)$ & $1(14.2 \%)$ & $2(28.4 \%)$ & $2(28.4 \%)$ & $1(14.2 \%)$ & $0(0 \%)$ \\
\hline $\begin{array}{c}\text { Citrobacter } \\
\text { spp }\end{array}$ & 3 & $0(0 \%)$ & $1(33.3 \%)$ & $0(0 \%)$ & $2(66.6 \%)$ & $0(0 \%)$ & $0(0 \%)$ & $0(0 \%)$ \\
\hline Proteus spp & 2 & $1(50 \%)$ & $1(50 \%)$ & $0(0 \%)$ & $0(0 \%)$ & $0(0 \%)$ & $0(0 \%)$ & $0(0 \%)$ \\
\hline $\begin{array}{c}\text { Enterobacter } \\
\text { spp }\end{array}$ & 1 & $1(100 \%)$ & $0(0 \%)$ & $0(0 \%)$ & $0(0 \%)$ & $0(0 \%)$ & $0(0 \%)$ & $0(0 \%)$ \\
\hline Total & 70 & $18(25.7 \%)$ & $17(24.2 \%)$ & $4(5.7 \%)$ & $12(17.1 \%)$ & $12(17.1 \%)$ & $3(4.2 \%)$ & $4(5.7 \%)$ \\
\hline
\end{tabular}

Table.8 Sample wise distribution of both ESBL and MBL positive isolates

\begin{tabular}{|l|l|l|l|l|l|l|l|l|}
\hline $\begin{array}{c}\text { Name of the } \\
\text { isolate }\end{array}$ & $\begin{array}{l}\text { No of } \\
\text { isolates }\end{array}$ & \multicolumn{1}{|c|}{ Urine } & \multicolumn{1}{|c|}{ Pus } & Sputum & $\begin{array}{l}\text { Tracheal } \\
\text { aspirate }\end{array}$ & $\begin{array}{c}\text { ET } \\
\text { secretions }\end{array}$ & $\begin{array}{c}\text { Central } \\
\text { line tip }\end{array}$ & $\begin{array}{c}\text { Peritoneal } \\
\text { fluid }\end{array}$ \\
\hline $\begin{array}{l}\text { Escherichia } \\
\text { coli }\end{array}$ & 7 & $1(14.2 \%)$ & $6(85.7 \%)$ & $0(0 \%)$ & $0(0 \%)$ & $1(14.2 \%)$ & $0(0 \%)$ & $0(0 \%)$ \\
\hline $\begin{array}{l}\text { Klebsiella } \\
\text { pneumoniae }\end{array}$ & 5 & $1(20 \%)$ & $1(20 \%)$ & $0(0 \%)$ & $0(0 \%)$ & $1(20 \%)$ & $0(0 \%)$ & $2(40 \%)$ \\
\hline $\begin{array}{l}\text { Pseudomonas } \\
\text { spp }\end{array}$ & 6 & $2(33.3 \%)$ & $1(16.6 \%)$ & $0(0 \%)$ & $1(16.6 \%)$ & $1(16.6 \%)$ & $1(16.6 \%)$ & $0(0 \%)$ \\
\hline $\begin{array}{l}\text { Acinetobacter } \\
\text { spp }\end{array}$ & 5 & $0(0 \%)$ & $0(0 \%)$ & $0(0 \%)$ & $3(60 \%)$ & $2(40 \%)$ & $0(0 \%)$ & $0(0 \%)$ \\
\hline $\begin{array}{l}\text { Citrobacter } \\
\text { spp }\end{array}$ & 2 & $1(50 \%)$ & $0(0 \%)$ & $0(0 \%)$ & $0(0 \%)$ & $1(50 \%)$ & $0(0 \%)$ & $0(0 \%)$ \\
\hline Proteus spp & 1 & $0(0 \%)$ & $0(0 \%)$ & $1(100 \%)$ & $0(0 \%)$ & $0(0 \%)$ & $0(0 \%)$ & $0(0 \%)$ \\
\hline Total & 26 & $5(19.2 \%)$ & $8(30.7 \%)$ & $1(3.8 \%)$ & $4(15.3 \%)$ & $5(19.2 \%)$ & $1(3.8 \%)$ & $2(7.7 \%)$ \\
\hline
\end{tabular}

In the present study highest percentage of ESBL and MBL production was seen in urine and pus isolates (Tables 5, 6, 7 and 8). Our results correlate with study of Grover et al., (2013), Oberoi et al., (2013) and Deshmukh et al., (2011). Early detection of ESBL and MBL positive isolates is mandatory not only for patient management but also for appropriate infection control measures to prevent the spread of the organisms (Uma devi et al., 2011)

MBL are enzymes that can hydrolyse wide variety of beta lactams including penicillins, 
cephems and carbepenems except aztreonam (Krishna, 2010). Production of MBL has vast therapeutic consequences since these organisms also carry multidrug resistance genes and the only viable option remains potentially toxic polymyxin B and colistin (Veenu gupta et al., 2013).

In conclusion the early detection of beta lactamase producing isolates would be important for the reduction of mortality rates for patients and also to avoid the intra hospital dissemination of such strains. Simple phenotypic screening tests are proved to be rapid and convenient for their detection in the clinical laboratory. Monitoring and judicious usage of cephalosporins and imipenem, periodic surveillance of antibiotic resistance patterns and efforts to decrease empirical antibiotic therapy would go a long way in addressing some of the problems associated with ESBL an MBL producer. To overcome the problem of emergence and the spread of multidrug resistant organisms, a combined interaction between the microbiologist, clinicians and infection control team is needed.

\section{References}

Anil Rajput, Bhavin Prajapati, Bimal Chauhan, Atit Shah, Toral Trivedi and Mina Kadam. 2012. Prevalence of Metallobeta-lactamases (MBL) producing Pseudomonas aeruginosa in a Tertiary care Hospital. Indian. J. Basic. Appl. Med. Res., 1(4): 304-308.

Bradford, P.A. 2001. Extended-Spectrum Lactamases in the 21st Century: Characterization, Epidemiology, and Detection of This Important Resistance Threat. Clin. Microbiol. Rev., 14(4): 933951.

Collee, J.G., Barrie, P., Marmion, A.G., Fraser, and A. Simmons. 2007. Mackie and McCartney Practical Medical Microbiology, 14th ed. Edinburgh:
Churchill Livingstone.

Clinical Laboratory Standards Institutes. 2016. Performance Standards for antimicrobial susceptibility testing, 26th International Supplement (M100-S26). Wayne, Pennsylvania, US A: National Committee for Clinical Laboratory standards.

Debasrita Chakraborty, Saikat Basu and Satadal Das. 2010. A Study on Infections Caused By Metallo Beta Lactamase Producing Gram Negative Bacteria in Intensive Care Unit Patients. American J. Infect. Dis., 6(2): 34-39.

Deshmukh, D.G., Damle, A.S., Bajaj, J.K., Bhakre, J.B., and Patwardhan, N.S. 2011. Metallo- $\beta$-lactamase-producing Clinical Isolates from Patients of a Tertiary Care Hospital. J. Lab. Physicians, 3(2): 93-97.

Kumar, E., K. Usha, B.V. Ramana, A Chaudhury, D.V.R., Sai Gopal. 2013. Prevalence of various $\beta$-lactamase (ESBL, AmpC and MBL) producing multidrug resistant clinical isolates of Acinetobacter spp. in a tertiary care hospital. Asian J. Pharm. Clin. Res., Vol 6, Suppl 4, 28-31.

Grover, N., Sahni, A.K., Bhattacharya, S. 2013. Therepeutic challenges of ESBLS and AmpC beta- lactamase producers in a tertiary care centre. Med. J. Armed Forces India, 69: 4-10.

Kamalraj, M., Kaviarasan, K., Padmapriya, G. 2015. Phenotypic detection of ESBL and MBL in clinical isolates of Non fermenters. Indian J. Basic and Appl. Med. Res., Vol.4, Issue 4, 470-475.

Kamble, D. 2015. Phenotypic detection of ESBL and MBL in Gram Negative bacilli isolated from clinical specimens. Int. J. Med. Res. Rev., 3(8): 866-870. doi: 10.17511/ijmrr.2015.i8.163.w,vol 3, No 8,2015 .

Krishna, B.V.S. 2010. New Delhi metallobetalactamases: A wake up call for microbiologists. Indian. J. Clin. Microbiol., 28(3): 265-66.

Kumar, S.H., Baveja, S.M., Gore, M.A. 2012. Prevalence and risk factors of Metallo $\beta$ lactamase producing Pseudomonas 
aeruginosa and Acinetobacter species in burns and surgical wards in a tertiary care hospital. J. Lab. Physicians, 4(1): 39-42.

Mita, D., Wadekar, K., Anuradha and D., Venkatesha. 2013. Phenotypic detection of ESBL and MBL in clinical isolates of Enterobacteriaceae. Int. J. Curr. Res. Aca. Rev., 1(3): 89-95.

Fam, N., M. Diab, H. Helmi, I. El-Defrawy. 2006. Phenotypic Detection of Metallo- $\beta$ Lactamases and Extended Spectrum $\beta$ Lactamases Among Gram Negative Bacterial Clinical Isolates. Egyptian J. Med. Microbiol., Vol. 15, No 4: 719-730.

Nazneen Siddiqui, Jayshree Bhakre, Ajit Damle, Jyoti Bajaj. 2014. Prevalence of Extended Spectrum Beta Lactamase (ESBL) Producing Gram Negative Bacilli from various clinical isolates. IOSR $J$. Dent. Med. Sci., Volume 13, Issue 9 Ver. VIII, 08-11.

Oberoi, L., Singh, N., Sharma, P., Aggarwal, A. 2013. ESBL, MBL and Ampc $\beta$ Lactamases Producing Superbugs Havoc in the Intensive Care Units of Punjab India, J. Clin. Diag. Res., Vol7(1): 70-73.

Prajapati, S.B., Oza, S.G., Mehta, S.J., Vegad, M.M. 2013. Prevalence Of Metallo-BLactamase Producing Pseudomonas Spp.(In Tertiary Care Hospital). NJIRM, 4(2): 68-70.

Rao, S.D., Kumar, E.A. 2013. Antimicrobial resistance and metallo $\beta$ lactamase in gram-negative isolates of hospitalacquired burn wound infections. J. Dr.
NTR Univ. Health Sci., 2: 181-5.

Shiju, M.P., Yashavanth, R., Narendra, N. 2010. Detection of Extended Spectrum BetaLactamase Production and Multidrug Resistance in Clinical Isolates of E. coli and K. pneumoniae in Mangalore. J. Clin. Diag. Res., 4: 2442-2445.

Tsering, D.C., Das, S., Adhiakari, L., Pal, R., Singh, T.S. 2009. Extended Spectrum Beta-lactamase Detection in Gramnegative Bacilli of Nosocomial Origin. $J$. Glob. Infect. Dis., 1(2): 87-92.

Umadevi, S., Kandhakumari, G., Joseph, N.M., Kumar, S., Easow, J.M., Stephen, S. and Singh, U.K. 2011. Prevalence and antimicrobial susceptibility pattern of ESBL producing Gram Negative Bacilli. J. Clin. Diag. Res., 5(2): 236-239.

Veenu gupta, Deepinder chhina and Amarjeet kaur. 2013. Incidence of metallo- lactamase (MBL) producing non fermenters isolated from respiratory samples in ICU patients. Int. J. Pharm. Bio. Sci., 4(2): (B) 580585.

Walsh, T.R., Toleman, M.A., Poirel, L., Nordmann, P. 2005. Metallo-betalactamases: the quiet before the storm? Clin. Microbiol. Rev., 18(2): 306-25.

Yong, D., Lee, K., Yum, J.H., Shin, H.B., Rossolini, G.M., Chong, Y. 2002. Imipenem. EDTA disk method for differentiation of metallo-beta-lactamaseproducing clinical isolates of Pseudomonas spp. and Acinetobacter spp. J. Clin. Microbiol., 40(10): 3798-801.

\section{How to cite this article:}

Narinder Kaur, Amandeep Kaur and Satnam Singh. 2017. Prevalence of ESBL and MBL Producing Gram Negative Isolates from Various Clinical Samples in a Tertiary Care Hospital. Int.J.Curr.Microbiol.App.Sci. 6(4): 1423-1430. doi: https://doi.org/10.20546/ijcmas.2017.604.174 